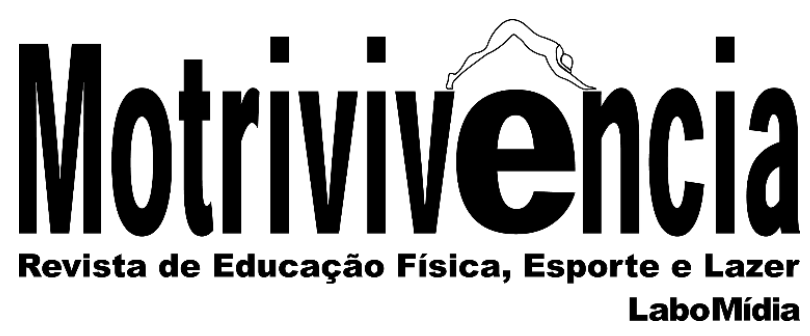

\title{
A inconfidência e insubordinação de Tântalo e suas reverberações no corpo político
}

\begin{abstract}
RESUMO
Este artigo propõe relacionar a trajetória e tragédia do mito grego Tântalo às conjunturas históricas, ressaltando o papel de destaque do corpo na construção da sociedade. Se alimenta de referências filosóficas, principalmente de Friedrich Wilhelm Nietzsche e de Arthur Schopenhauer e literárias de Franz Kafka e Augusto dos Anjos para poder instaurar um olhar sobre o corpo enquanto instrumento reflexivo e, por conseguinte, refém das barbáries corporais e psicológicas na história.
\end{abstract}

PALAVRAS-CHAVE: Tântalo; Corpo; Tragédia; Sociedade

\section{Sandro Borelli}

Mestre em Educação Física Universidade Estadual de Campinas UNICAMP

Faculdade de Educação Física Campinas, São Paulo, Brasil sandroborelli13@gmail.com

(ㄱ) https://orcid.org/0000-0002-1681-8953

Flávia Brassarola Borsani Marques

Mestre em Arte Educação Universidade Estadual de São Paulo - UNESP Instituto de Artes

São Paulo, São Paulo, Brasil

flaviaborsani@gmail.com https://orcid.org/0000-0003-0365-5048

Odilon José Roble Doutor em Educação Universidade Estadual de Campinas UNICAMP

Departamento de Educação Campinas, São Paulo, Brasil roble@,unicamp.br https://orcid.org/0000-0003-1579-0116 


\title{
The inconfidence and insubordination of Tantalus and its reverberations in the politial body
}

\begin{abstract}
This article proposes to relate the trajectory and tragedy of the Greek myth Tantalus to the historical conjunctures, emphasizing the prominent role of the body in the construction of the society. It feeds on philosophical references, especially from Friedrich Nietzsche and Arthur Schopenhauer and from literary works by Franz Kafka and Augusto dos Anjos, in order to establish a look at the body as a reflexive instrument and, therefore, a hostage to the corporal and psychological barbarism in history.
\end{abstract}

KEYWORDS: Tantalum; Body; Tragedy; Society

La incofidencia e insubordinación de Tántalo y sus reverberaciones em el cuerpo político

\section{RESUMEN}

Este artículo propone relacionar la trayectoria y tragedia del mito griego Tántalo a las coyunturas históricas, resaltando el papel destacado del cuerpo en la construcción de la sociedad. Se alimenta de referencias filosóficas, principalmente de Friedrich Wilhelm Nietzsche y de Arthur Schopenhauer y literarias de Franz Kafka y Augusto de los Ángeles para poder instaurar una mirada sobre el cuerpo como instrumento reflexivo y, por consiguiente, rehén de las barbarie corporales y psicológicas en la historia.

PALABRAS-CLAVE: Tántalo; Cuerpo; Tragedia; La sociedad 


\section{TÂNTALO - O INCONFIDENTE}

Ao iniciar estas reflexões, propomos a licença poética de relacionar o mito grego de Tântalo a um importante personagem da história política brasileira, chamado Joaquim José da Silva Xavier (1746 - 1792), conhecido como Tiradentes. Nossa proposta se dá por conta da possível similaridade dos delitos de ambos, nas condenações e nos castigos: um foi condenado a cumprir pena por toda a eternidade, o outro, sentenciado à morte por enforcamento.

Segundo sentença ${ }^{1}$ promulgada em 1792 por Sebastião Xavier de Vasconcelos ${ }^{2}$ e outros:

[...] Mostra-se que entre os chefes e cabeças da conjuração, o primeiro que suscitou as ideias de república foi o réu Joaquim José da Silva Xavier, por alcunha o Tiradentes, alferes que foi da Cavalaria paga da Capitania de Minas Gerais, o qual há muito tempo que tinha concebido o abominável intento de conduzir os povos daquela Capitania a uma rebelião pela qual subtraíssem da justa obediência devida à dita Senhora formando para este fim publicamente discursos sediciosos que foram denunciados ao Governador de Minas antecessor do atual, e que então sem nenhuma razão foram desprezados como consta a folhas 74 folhas 68 verso folhas 127 verso e folha 2 do apêndice número 8 da devassa principiada nesta cidade; e suposta que aqueles discursos não produzissem naquele tempo outro efeito mais do que o escândalo a abominação que mereciam, contudo como o Réu viu que o deixaram formar impunemente aquelas criminosas práticas [...]. (COUTINHO et al, 1792).

Tiradentes foi considerado um traidor da coroa portuguesa por insuflar uma revolta do povo pobre contra as altas taxas de impostos cobradas pela monarquia e tramar a independência do Brasil, até então, colônia de Portugal. Ele não foi o único acusado e capturado pelas tropas a serviço da monarquia portuguesa, havia outros insurgentes, jovens oriundos de famílias tradicionais com estudos na Europa, com ideias consideradas libertárias que iam de encontro ao sistema vigente. Tiradentes, contudo, era de origem social diversa, possuindo uma condição bastante humilde. Talvez, por essa discrepância de classe social foi o único dos insurgentes que não mereceu clemência da rainha Maria I, sendo enforcado em praça pública, em seguida, esquartejado e salgado a fim de que suas vísceras se preservassem por um tempo maior para serem expostas em diversos locais da região, com o intuito de manter a população sob o refúgio do medo. Seu sangue foi usado pelos representantes do Estado para cunhar um documento oficial, informando que a sentença havia sido cumprida, muito provavelmente como forma de ratificar o poderio domesticador e doutrinador instaurado para manter o cidadão obediente e temeroso. Um indivíduo que ousou desafiar o poder estrangeiro-invasor, estabelecido à custa de muita opressão e sangue derramado.

${ }^{1}$ Disponível em: http://www.historianet.com.br/conteudo/default.aspx?codigo=612. Acesso em: 05/02/18. ${ }^{2}$ Chanceler da rainha. 
Por conta de uma morte tão cruel e, ao mesmo tempo, épica, em alguns aspectos semelhante a um roteiro de espetáculo trágico grego, a história acabou sendo condescendente com esta figura, perpetuando-a como um herói que tentou se opor ao regime de opressão de sua época, em que países que eram potências bélicas, sobrepunham-se aos menos desenvolvidos ou militarizados.

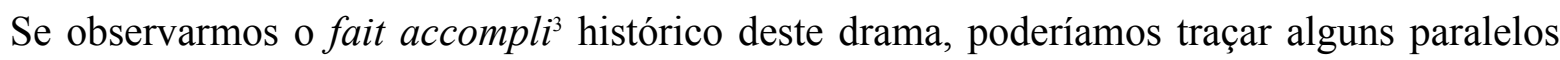
com os aspectos trágicos de alguns mitos gregos. Talvez seja plausível delinear perspectivas entre este fato da história brasileira e Tântalo, com suas ações que o levaram à punição eterna e (ou) a revolucionários ligados às lutas pelas causas sociais contra a opressão, tais como Simon Bolívar (1783-1830), Carlos Marighella (1911-1969), Che Guevara (1928-1967) e tantos outros.

Quando apresentamos a figura do Rei da Frígia, filho de Zeus, em algumas versões, falamos de um soberano abastado, famoso e influente, principalmente por conta de sua nobre origem. Em razão do seu prestígio junto à cúpula divina do Olimpo, a ele foi dado o direito de se sentar à mesma mesa, junto a seu pai e outros deuses e, com isso, poder conhecer códigos inacessíveis aos mortais, inclusive sendo possível saborear as iguarias sagradas do Olimpo. Com os conhecimentos adquiridos por meio desta convivência íntima e por ter tido contato com as delícias provindas dos manjares dos deuses, que concediam a imortalidade a quem as experimentasse, Tântalo, em ato de extrema ousadia, trai seu pai, distribuindo valiosos segredos aos meros mortais.

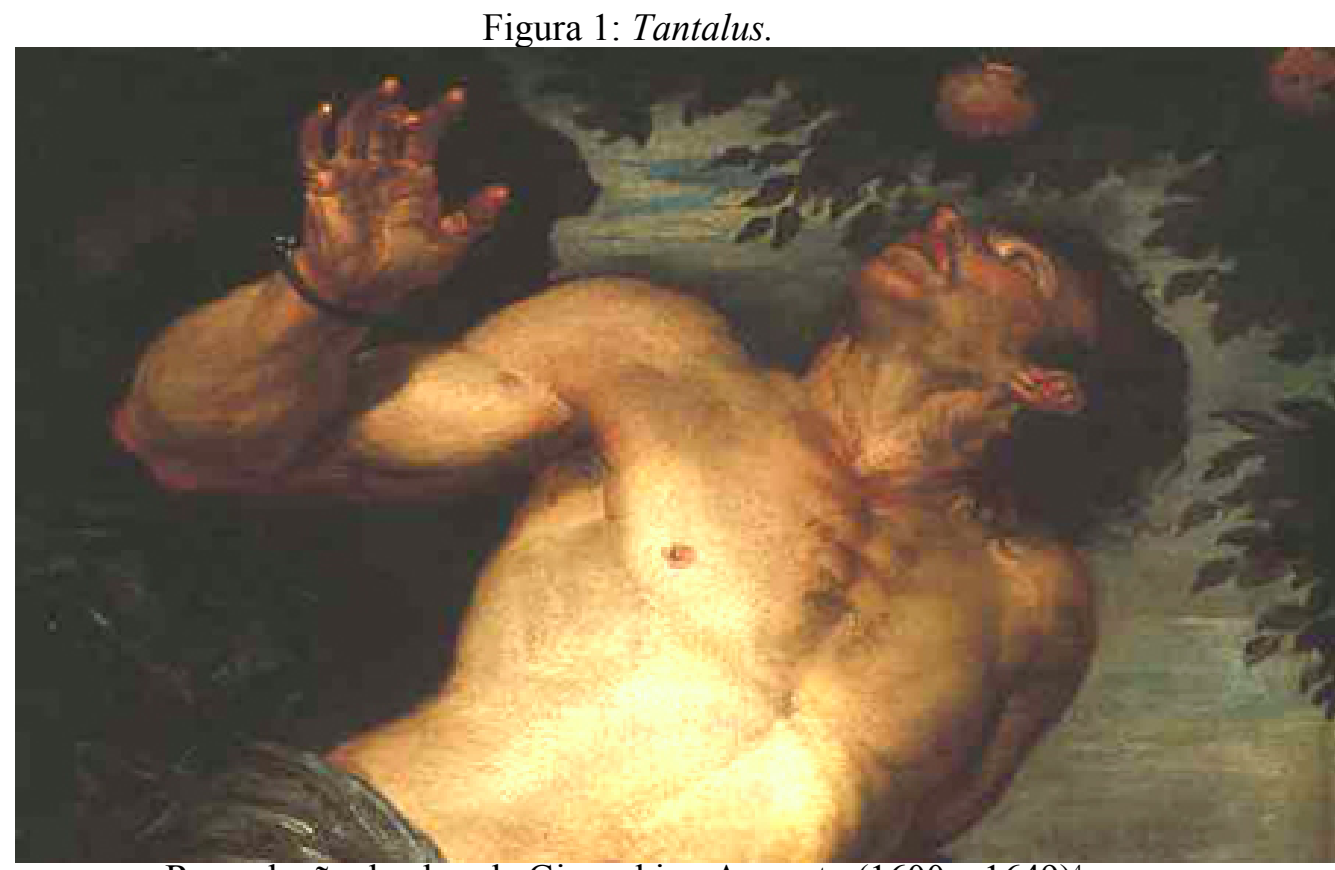

Reprodução da obra de Gioacchino Assereto $(1600$ - 1649).

${ }^{3}$ Latim. Tradução: fato consumado.

${ }^{4}$ Disponível em: https://commons.wikimedia.org/wike/file:Tantalus Gioacchino Assareto circa1640s.jpg. Acesso em: 2 de janeiro de 2018 . 


\section{Insubordinação}

Seu grave delito acabou sendo descoberto pela alta cúpula divina e, por conta disso, punido e condenado ad eternum ${ }^{5}$ a passar sede e fome no Tártaro, um lugar com água abundante ao seu redor, mas sendo incapaz de sorvê-la, assim como fartas frutas em árvores, as quais não conseguia alcançar para saciar sua fome. Uma eterna tortura física e psicológica, sem qualquer possibilidade de acesso à morte.

Brandão assim definiu Tântalo, em sua publicação intitulada Mitologia Grega:

O tema mítico de Tântalo, na luta interior contra a vã exaltação, simboliza a elevação e a queda. Seu suplício corre paralelo com sua hamartia ${ }^{6}$ o objeto de seu desejo, a água, os frutos, a liberdade, tudo está diante de seus olhos e infinitamente distante da posse. No fundo, Tântalo é o símbolo do desejo incessante e incontido, sempre insaciável, porque está na natureza do ser humano o viver sempre insatisfeito. Quanto mais se avança em direção ao objeto que se deseja, mais este se esquiva e a busca recomeça. (BRANDÃO, 2009, p. 79).

Sendo assim, é possível avaliar que os castigos, as torturas e os martírios se perpetuam porque carregamos um invólucro corpóreo de intensa sensibilidade à dor, um fardo pesado e punitivo diário. $\mathrm{O}$ corpo parece nos afirmar diariamente que viver é interagir a todo o momento com o sofrimento físico e psicológico à espera de um equívoco que deverá, em algum instante, ser fatal. Um aviso contínuo de que a vida é um produto perecível com prazo de validade. Um recado constante de que viver não tem sentido prático algum, como nos afirmou Arthur Schopenhauer em vários momentos na sua obra.

A própria questão do desejo é assumida por Schopenhauer em sentido muito semelhante à interpretação de Brandão sobre Tântalo. A inconfidência de Tântalo é resultado do desejo, ou da vontade, como prefere Schopenhauer. Contudo, para além da esfera do sujeito, encontramos a disputa que esse personagem propõe ao poder acima dele, o inevitável conflito entre heróis e deuses. O que também encontramos nesse momento é o que Nietzsche denominou "Vontade de Poder" , dando outra interpretação a este conceito filosófico. Tântalo não quis se subordinar aos deuses e, por conta disso, revela os segredos que, fora do Olimpo, colocaria em risco o poder da alta cúpula divina.

O grande valor simbólico de Tântalo também pode ser reconhecido e exaltado exatamente pelo seu delito, por que não? Ou seja, abre-se uma possibilidade de interpretá-lo como um

${ }^{5}$ Latim. Tradução: eternamente.

${ }^{6}$ Grego. Falta ou erro causador da queda de um herói trágico.

${ }^{7}$ Assim como os ferormônios, o humano exala em todo momento a "Vontade de Poder". Segundo Nietzsche (2005, p. 19): "Uma criatura viva quer antes de tudo dar vazão a sua força - a própria vida é vontade de poder: a autoconservação é apenas uma das indiretas, mais frequentes consequências disso." 
personagem transgressor da mitologia grega pela sua ousadia desmedida em passar informações sigilosas do poder supremo aos mortais. Sendo assim, entendemos ser admissível abrir mais um leque de entendimentos acerca do seu ato e inseri-lo no campo simbólico das relações humanas, pois pode ser entendido como uma insubmissão dos mais fracos em relação aos poderosos, propondo mais uma entre tantas batalhas no mundo por equidade entre os que dominam e os dominados, entre os que têm e os desprovidos, ou, entre a elite e os pobres, casa grande e senzala, na eterna luta pelo poder.

Por este ato de ousadia e rebeldia, cogitamos ser plausível considerar o rei da Frígia como um dos maiores e mais importantes subversivos da mitologia grega. Uma espécie de Zumbi dos Palmares $^{8}(1655$ - 1695), outro insurgente, além de Tiradentes, contra a Coroa Portuguesa. O ato e castigo de Tântalo geraram algumas conclusões que caíram no gosto popular, uma delas é a afirmação de que "Quem muito quer nada tem", uma frase que parece conveniente a um Estado domesticador ou mesmo a uma moral judaico-cristã, para os quais o querer ser ou ter costuma ser entendido como um atrevimento social ou até mesmo falha de caráter.

Deparamo-nos aqui na fraqueza da "Moral de Rebanho", tão execrada e combatida por Nietzsche, em busca do indivíduo liberto destas amarras. Schopenhauer também nos assegura, em $A$ Vontade De Amar, que:

O mundo é um vasto campo de batalha onde os seres somente devorando-se uns aos outros conseguem conservar e defender a vida; onde todo animal carnívoro é o túmulo vivo de tantos outros; onde o viver significa sofrer longos tormentos; onde a capacidade para a dor aumenta na proporção da inteligência, e atinge, portanto, no homem o mais elevado grau. (SCHOPENHAUER, 1985, p. 89).

A tragédia de Tântalo nos permite avaliar a vida como estando inserido em uma gaiola, ou seja, com uma ampla visão de mundo ao seu redor, onde tudo, naturalmente, apresenta-se muito próximo, um mundo pujante e fascinante esperando poder ser acessado, mas apenas se apresentando como uma ilusão, ou tão somente, como possibilidades aparentemente concretas de domínio de uma situação, mas impossível de revertê-la em realidade palpável. Apenas uma vontade de poder desencarnada, interditada pela lógica da vida, um eterno devir, "uma transcendência que não se realiza". Um Tântalo, de certo modo, também transformado em fênix, aprisionado no seu dramático renascer das cinzas. Como em um destino trágico, tudo está próximo de se concretizar, a tortura parece se instalar exatamente aí.

\footnotetext{
${ }^{8}$ Disponível em: http://brasilianafotografica.bn.br/?tag=zumbi-dos-palmares. Acesso em: 30/01/18.

${ }^{9}$ Disponível em: https://revistausina.com/2016/12/30/augusto-dos-anjos-poemas-nao-recolhidos-em-livro-pelo-autor/. Acesso em: 24/02/18.
} 
Quando mencionamos tortura, tragédia e dor, provavelmente, estamos evocando o corpo na sua mais primitiva essência, não há martírio sem corpo que o possa receber, não há sentido observar um espetáculo com fogueira condenatória, se não houver uma carcaça ainda com vida para ser o astro principal da barbárie, como ocorreu, por exemplo, com Joana d'Arc ${ }^{10}$ (1412-1431). Ou seja, como em uma cena coreográfica ou teatral, não há possibilidade real de refletir e abordar os tormentos dos heróis gregos ou dos mitos, caso não trouxermos o corpo para o centro da discussão. Sem ele (corpo), tudo estará aprisionado no campo das ideias, ou do vir a ser. Mesmo nos castigos psicológicos, o alvo parece ser sempre ela, a carne, pois é nela que se obterá a dor e o padecimento.

\section{Insólito}

A atração incontrolável em torturar o outro e subestimá-lo parece ser insofismável, uma espécie de excitação sexual permanente à crueldade, que mantém o indivíduo apto ao coito a qualquer momento. Nesta insólita relação sexual que menciono, a sensação de estar no lugar do ativo se confunde com o do passivo, um ato que manifesta uma relação de duas vias, ou seja, o prazer em proporcionar a dor no outro se assemelha com o de receber, um sadomasoquismo intermitente e insaciável. Um prazer em si mesmo, muito próximo de uma masturbação solitária.

A impressão que se tem, é de que não somos levados totalmente aos desvarios desta natureza porque a sociedade se baseia na conveniência hipócrita, na busca do cumprimento das leis do Estado ou de um lugar no reino dos céus.

Relatamos aqui uma experiência vivida por Sandro Borelli, um dos autores deste artigo na vivência de um processo criativo para a gestação de um espetáculo de dança, intitulado Colônia Penal $^{11}$, inspirado na tortura da ditadura militar brasileira $(1964-1985)^{12}$ e na obra homônima de Franz Kafka.

Durante meses a fio, na construção cênica e criação dos movimentos coreográficos, que necessariamente (por opção minha) deveriam retratar os atos cometidos pelos torturadores e sentidos pelos torturados da maneira mais objetiva e próxima possível, uma estranha sensação de prazer que o cooptou durante o trabalho criativo. Quanto mais criava situações corporais que remetiam às barbáries da época retratada, mais tinha vontade de preservar a situação. Em vários momentos do processo, flagrei-me gargalhando por conta das dificuldades físicas e emocionais enfrentadas pelos intérpretes. Colônia Penal ${ }^{13}$ estreou em São Paulo, em julho de 2013, com

\footnotetext{
${ }^{10}$ Disponível em: https://www.ebiografia.com/joana darc/. Acesso em: 24/02/18.

${ }^{11}$ Disponível em: $\underline{\mathrm{http}: / / c u l t u r a . e s t a d a o . c o m . b r / n o t i c i a s / g e r a l, d i a l o g o-p o s s i v e l-e-n e c e s s a r i o-e n t r e-d a n c a-e-p o l i t i c a-~}$ imp-,1053054. Acesso em: 31/01/18.

${ }^{12}$ Disponível em: https://brasil.elpais.com/brasil/2014/12/10/politica/1418212909 598291.html. Acesso em $24 / 02 / 18$.
} 
duração de aproximadamente 60 min de muita perversidade e de extrema violência corporal, mas a reflexão que pude fazer nos dias que vieram a seguir da estreia foi o quanto somos criadores e criaturas das nossas próprias mazelas, sádicos por essência.

Em certos momentos, agimos como abutres embrutecidos em torno de uma carcaça abandonada, disputando nacos de ventres podres. A morte por si só, já se nos apresenta como uma espécie de grand finale $^{14}$, não há como não perecer sem estar inserido em um momento espetaculoso. Qualquer morte, por mais esperada que seja, deverá apresentar um pathos ${ }^{15}$, o

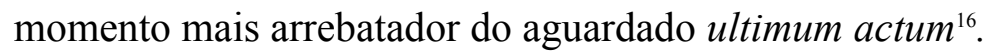

\section{Figura 2 -Cena de Colônia Penal (2013).}

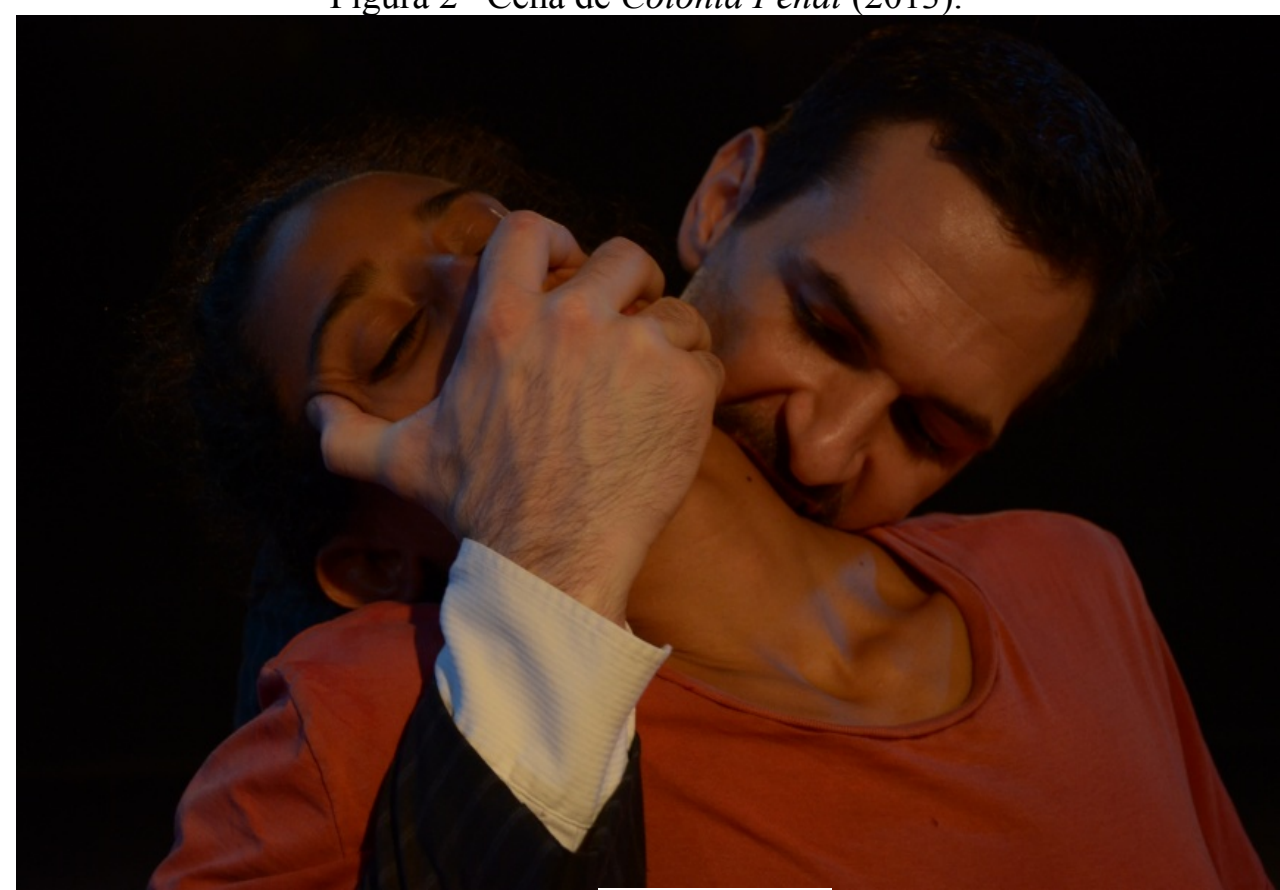

Crédito: Júnior Cecon ${ }^{17}$.

A grande cena esperada por todos no teatro. Como, por exemplo, no solo do ballet $A$ Morte do Cisne $^{18}$, no qual a plateia aguarda ansiosamente o desenlace do belo animal de plumas brancas, a fim de poder descarregar as emoções represadas durante o sofrimento da ave, para acessarem o tão esperado momento catártico. É possível pensar, ainda como exemplo, que se Romeu e Julieta, de William Shakespeare, na tragédia escrita entre 1591 e $1595^{19}$, não tivessem um final funesto e sim

\footnotetext{
${ }^{13}$ Disponível em: https://youtu.be/2HIqW9oVDz4. Acesso em: 31/01/18.

${ }^{14}$ Francês. Final glorioso.

${ }^{15}$ Grego. Tradução: paixão, excesso, catástrofe.

${ }^{16}$ Latim. Tradução: último ato.

${ }^{17}$ Inspirada na obra de Franz Kafka e na tortura da Ditadura militar brasileira. Intérpretes: Mainá Santana e Alex Merino. Fonte: http://www.ciacarneagonizante.com.br/. Acesso em: 12/03/18. As fotos dos espetáculos, tais como esta, são do arquivo da Cia carne Agonizante, da qual os autores deste texto possuem liberação para utilizá-las e publicá-las.

${ }^{18}$ Disponível em: https://lituraterre.com/2010/12/11/a-morte-do-ciste-a-morte-da-arte/.Acesso em: 15/01/18.

${ }^{19}$ Disponível em: https://www.culturagenial.com/romeu-e-julieta-de-william-shakespeare. Acesso em: 13/03/19.
} 
outro mais agradável, talvez muito do impacto e legado da obra seriam reduzidos.

Quando abordamos o filho inconfidente de Zeus, imediatamente o corpo surge como ator principal das tragédias humanas, quando falarmos em tortura, será sempre ressaltado o destaque destinado a ele como o de receptor maior das barbáries sociais conduzidas por um Estado, por vezes, doutrinador, opressivo e assassino.

\section{Autofagia Incessante}

Além da morte, a desgraça humana vem sendo incessantemente abordada nos ambientes artísticos e filosóficos das mais variadas formas, as tragédias gregas, de certo modo, comprovam o quanto este universo tem seduzido o homem desde os primórdios da civilização ocidental. Cada tijolo posicionado na construção da história da sociedade foi fixado com muito sofrimento e sangue derramado nos campos de batalhas. Portanto, nada mais adequado afirmar nestas reflexões o quão atraente pode ser transitar por caminhos aparentemente obscuros, onde o fracasso humano em todos os níveis, a desesperança do indivíduo no seu eterno devir, exibe-se a todo instante. Seria praticamente impossível conseguir gestar obras cênicas se não houvesse daemones $^{20}$ neste universo.

É sabido que para a terra se tornar fértil, as suas profundezas deverão estar repletas de restos mortais de todo tipo, assim, no futuro, produzirão alimentos que nutrirão os viventes, que serão os próximos a perecer e, consequentemente, novamente engolidos pelo solo. Uma lógica impossível de ser negada, um processo orgânico de transformação ad continuum $^{21}$ através de uma autofagia incessante e necessária. Um círculo que gira em torno de si mesmo, que faz lembrar Íxion, outro membro da estirpe de Tântalo e Sísifo, considerados vilões na mitologia grega, mas, entendo ser pertinente serem também compreendidos como revolucionários, fiéis representantes da insubordinação, mensageiros da imortalidade, antítese da efemeridade.

Uma aparente desordem, que nada mais é do que a luta pela manutenção da vida e da espécie, como tanto nos afirmou Arthur Schopenhauer, pode muito bem ser encaixada em uma batalha épica de grandes proporções pela manutenção da existência como a única verdade inconteste. É exatamente aí que é possível observar as semelhanças entre o mito de Tântalo e o artista do corpo, mas apenas quando estão em conjugação o momento da criação ao sentimento de ira, da denúncia e de insubordinação.

Apresentamos mais um depoimento pessoal do autor, dado ao projeto de videodança intitulado “Gestos Mortos”, em 201122, que entendo ser pertinente incluir nestas reflexões:

\footnotetext{
${ }^{20}$ Disponível em: https://aminoapps.com/c/mitologicpt/page/blog/daemones-os-intermediarios-mitologiagrega/lDw7 wVFQuXk0QERdaqxERpXa1w4Jqaqrv. Acesso em: 13/03/19.

${ }^{21}$ Latim. Tradução: contínuo.
} 
Jamais conseguiria criar alguma coisa se eu não tivesse demônios na minha cabeça, sabe? Jamais conseguiria criar alguma coisa se eu me sentisse pleno, jamais conseguiria criar algo se eu estivesse bem, inteiramente resolvido interiormente como pessoa, a minha relação com o mundo, sabe? Este tipo de coisa para mim é muito importante, me faz mais gente, sabe?

A arte não pode ser contemplativa, não deve ser para mim. Por exemplo, se eu chegar para você e disser "Hoje estou bem, estou ótimo, acordei feliz e estou inspirado para criar algo", você não vai criar coisa alguma. Você pode até criar, mas...

Estes fantasmas, estes problemas existenciais, são a verdadeira droga do artista. Quando falo de fantasmas, eu falo de perturbações, de tudo relacionado a isso. Existir já é uma perturbação.

Você lidar com você mesmo já é uma grande perturbação, e também quanto mais vamos aprendendo e adquirindo conhecimento das coisas, mais perturbado você vai ficando, mais triste você vai ficando, é assim, sempre foi assim.

Talvez o maior perigo do conhecimento pleno, do conhecimento total, é o aniquilamento físico, é de repente a pessoa perceber que não vale a pena existir. Existir é apenas um não ter sentido. Bom, mas agora eu comecei a viajar, eu e as moscas [...]. (BORELLI, 2011).

Há incontáveis modos de ver e sentir o mundo que se apresenta para nós a todo o instante, por vezes, parecemos ser uma usina com a finalidade de produzir um tipo de energia finita a partir da matéria-prima encontrada na vontade, tal qual Schopenhauer nos apontou em sua obra. No âmbito artístico e criativo, esta mesma vontade parece transitar potente a todo instante para várias direções, dentre estes vários caminhos, podemos inserir o da gestação de obras artísticas a partir de um olhar crítico ao modus operandi $i^{23}$ da sociedade. Um tipo de proposição que procura, a todo o momento, recusar o maniqueísmo estético.

Parece que para a arte ser avassaladora e demolidora, será necessário chafurdar no caos e no "pântano das desgraças humanas" (em latim, pastu paludis virecta cladium consaepta). Um sentimento íntimo de desordem deverá ser posto à mesa, como em um jogo de cartas, onde o risco deverá estar presente a cada lance jogado e a derrota deverá ser o resultado mais lógico.

\footnotetext{
${ }^{22}$ Disponível em: https://youtu.be/mxyjGDK2GKk. Acesso em: 20/09/18.

${ }^{23}$ Grego. Tradução: expressa o conceito de excelência ou virtude.
} 


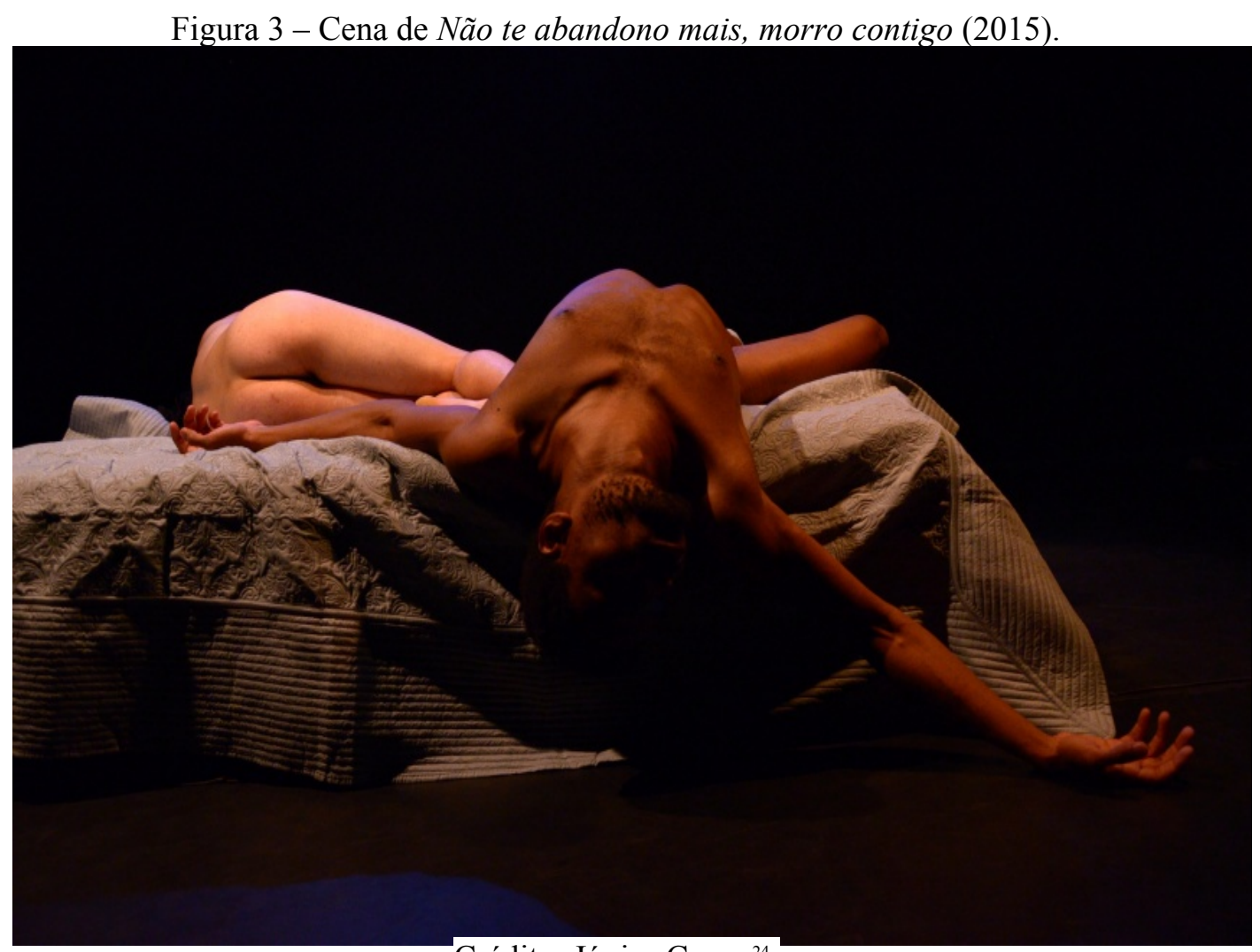

Crédito: Júnior Cecon ${ }^{24}$.

Leiamos Nietzsche nesse sentido:

Aquela repugnante beberagem mágica de volúpia e crueldade viu-se aqui impotente: somente a maravilhosa mistura e duplicidade dos afetos do entusiasta dionisíaco lembram - como um remédio lembra remédios letais - aquele fenômeno, segundo o qual os sofrimentos despertam o prazer e o júbilo arranca do coração sonidos dolorosos. Da mais elevada alegria soa o grito de horror ou o lamento anelante da perda irreparável. (NIETZSCHE, 2013, p. 31).

Como toda concepção criativa que tenha a intenção de desnudar o indivíduo ou sequestrá-lo do adestramento, tudo leva a crer que serão necessárias implosões íntimas que alterem os estados psíquicos para que um manifesto artístico surja de fato. São as rupturas ou quebras de paradigmas que poderão proporcionar um renascer dos escombros.

Sobre a morte, lemos em Schopenhauer (2001, p. 35): “A morte ou a vida do indivíduo não importa nada: é esta sua categórica afirmação. Ela expressa esse fato abandonando a vida de cada animal, e também a do próprio homem, aos acasos mais insignificantes, sem intervir por sua salvação".

\footnotetext{
${ }^{24}$ Inspirada na obra homônima de Franz Kafka. Com Everton Ferreira e Alex Merino. Disponível em: http://www.ciacarneagonizante.com.br/. Acesso em: 23/03/18.
} 
É da nossa natureza relutarmos em aceitar a morte, insistimos a todo custo na busca da prorrogação de poder estar por aqui, nestas paragens, não importa de que maneira. A possibilidade factual de não existirmos mais parece ser aterrorizante e desastrosa, pois queremos ser algo que possivelmente nunca seremos. Talvez, por isso, temos a tendência de reverenciar nossos mártires através da música, da poesia, em alguns momentos na dança e no teatro.

A morte nos causa comoção, o batimento cardíaco aumenta consideravelmente quando nos defrontamos com o perigo eminente de perecermos e nos compadecemos ao máximo quando alguém próximo ou idolatrado encontra seu fim. Não sabemos ao certo se Tântalo preferiu a morte ao invés de viver em castigo eterno, ou se aceitou passivamente seu calvário solitário, simplesmente acatou a sentença deferida a ele.

Ademais, é impressionante como os castigos aplicados a Tântalo e a Sísifo suscitam relações com métodos de torturas determinados pelos vencedores aos vencidos na sociedade ocidental e, praticamente, entregam-nos roteiros e cenas prontas para serem aproveitadas, inspiradas ou baseadas nos sofrimentos experimentados por esses mitos. Incluo aqui, também, Íxion ${ }^{25}$, não tão conhecido como o rei da Frígia e de Éfira, mas de importância simbólica e cultural do mesmo porte.

\section{Culpa e Corpo}

Talvez possamos relacionar culpa e corpo como amantes inseparáveis das agonias humanas se compreendermos a vida ou existência como uma sucessão constante de sofrimentos congregados. Pelo visto, o sentido da vida somente poderia ser encontrado fora dela, na solidão do niilismo, no vazio do nada.

Como na poesia "O Lamento das Coisas", do poeta Augusto dos Anjos, escrita no início do século passado, no ano de 1914, em terras paraibanas:

Triste, a escutar, pancada por pancada, a sucessividade dos segundos, ouço, em sons subterrâneos, do Orbe oriundos, o choro da Energia abandonada! É a dor da força desaproveitada, o cantochão dos dínamos profundos, que, podendo mover milhões de mundos, jazem ainda na estática do nada! É o soluço da forma ainda imprecisa... Da transcendência que se não realiza... Da luz que não chegou a ser lampejo... E é em suma, o subconsciente aí formidando, da natureza que parou, chorando, no rudimentarismo do Desejo! (ANJOS, 2001, p.181).

Outra questão, que consideramos possível anunciar nas reflexões construídas nesta pesquisa, é a relação entre Tântalo e a loucura. Analisando a insanidade no âmbito poético, é imaginável compreendê-la como um modo de fomentar, perceber e até mesmo de pensar o mundo. Neste

\footnotetext{
${ }^{25}$ Disponível em: https://www.webartigos.com/artigos/o-mito-dos-centauros/73446. Acesso em: 03/01/18.
} 
universo, as regras são outras e construídas a cada momento, a noção de tempo, de ética e de moral se diferem da normalidade estabelecida pelo Estado domesticador, criando a figura do "marginal" urbano com o propósito de separar o que é socialmente repelido por uma coletividade contaminada pelo vírus da intolerância e do higienismo social.

Acompanhamos a premissa de que onde há poesia, há loucura, onde a insanidade habita, o grotesco estará presente como forma desafiadora dos padrões estabelecidos pelo culturalismo conservador.

Leiamos uma consideração sobre a questão do grotesco nas artes da cena:

Ao representar o ser humano em sua condição mais primitiva, as personagens grotescas se distanciam da ideia de comportamento civilizado. Essa inversão de valores, disforme e obscena, torna as personagens estranhas e ridículas, pois quebra regras básicas de organização social. Essa ponte entre o humano civilizado e sua inexorável condição natural alimenta o incômodo, pertinente ao grotesco. (ROBLE, 2016).

O corpo bizarro, estranho, esquisito e burlesco amedronta o indivíduo capturado pelo sonho do poder efêmero, pois esta condição é sinônimo de impossibilidade total de crescimento social, então, ele o repele de todas as maneiras e de todas as formas possíveis. Também podemos analisar a insanidade e o bizarro como uma vertigem fascinante de uma eminente queda ao abismo ou a uma metralhadora em ação, alvejando a hipocrisia, as regras e as obviedades.

Figura 4- Cena de A Metamorfose (2002).

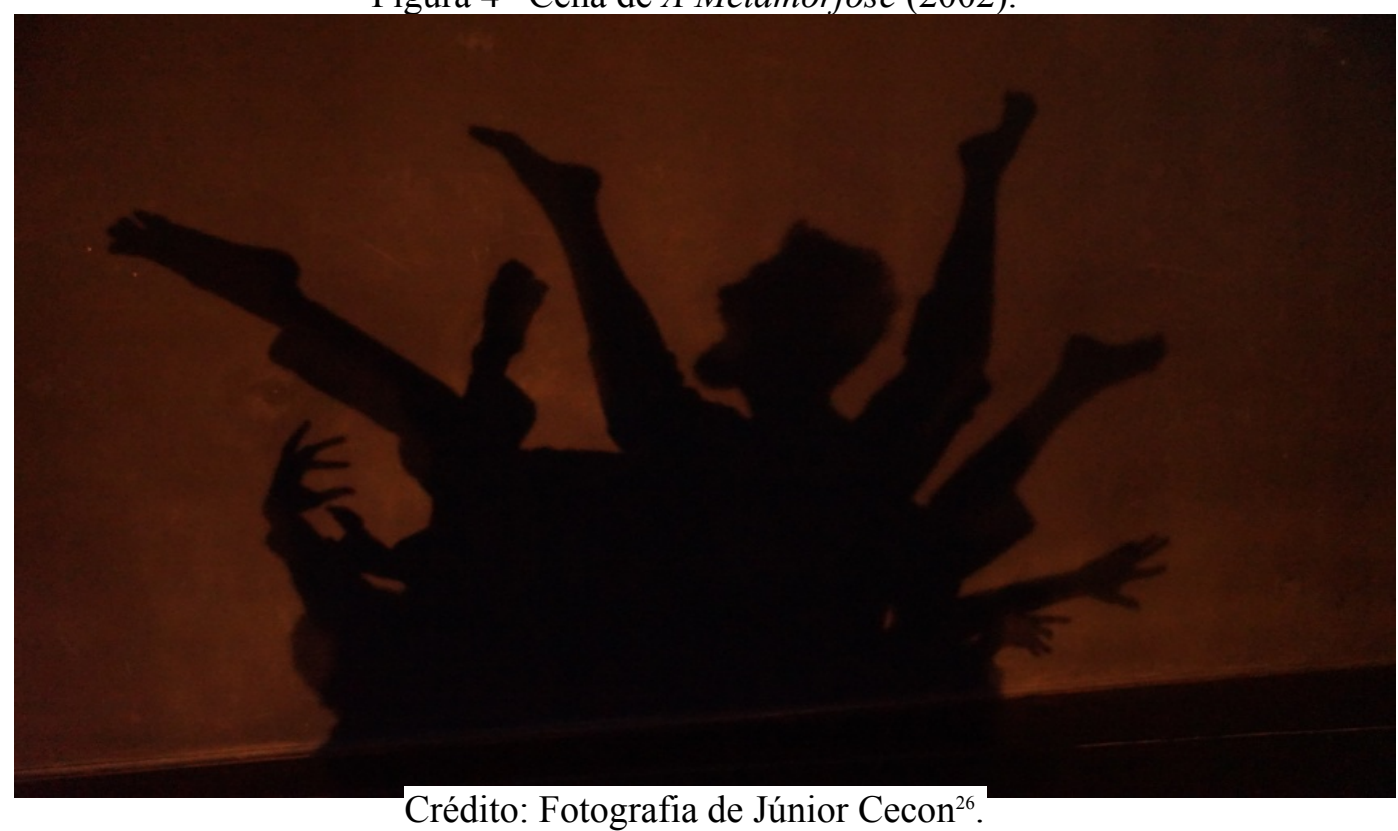

${ }^{26}$ Inspirada na obra homônima de Franz Kafka. Com elenco da Cia. Carne Agonizante. Disponível em: http://www.ciacarneagonizante.com.br/. Acesso em: 13/05/18. 
Se a genialidade pode ser também entendida como uma possível ramificação da loucura, pois são ambientes onde tudo é viável, instantaneamente, Nietzsche nos vem à memória, pois o homem que concebeu $O$ Anticristo, em 1895, terminou seus dias em Weimar, na Alemanha, em completa demência mental.

Mencionamos uma reflexão de Arthur Schopenhauer acerca do gênio, em A Metafísica do Belo:

Um erudito é aquele que estudou muito de sua época e das precedentes; já um gênio é aquele de quem sua época e as vindouras têm muito a estudar.

$\mathrm{O}$ que me conduziu a essa abordagem foi o fato de ter encontrado em manicômios, sujeitos com inegáveis indícios de disposições geniais que, devido à raridade proporcional da loucura, mais até que o gênio, não podem ser atribuídas ao acaso, mas justamente confirmam o que sempre se observou e eu explicitei - que o gênio de algum lado faz fronteira com a loucura, sim, com facilidade a ultrapassa. (SCHOPENHAUER, 2003, p. 79).

\section{Sentença e Pena}

Parece não haver dúvida de que o atrevimento praticado por Tântalo, ao questionar, ludibriar e tentar conceber um poder paralelo ao de Zeus, fez com que ele se tornasse uma espécie de mentor dos indomáveis, dos heróis e dos sabotadores do poder consolidado.

Permitimos considerar esse filho infiel de Zeus como um audacioso destemido e, até mesmo, um herói ou mais, um anti-herói kafkiano, pois, certamente, ele devia ter a convicção de que seria quase impossível vencer seu pai, mas, mesmo assim, seguiu seus próprios impulsos utópicos, repletos de devaneios. Tântalo parecia saber que fatalmente seria descoberto, porém, aceita o embate. Deste modo, a energia revolucionária desse mito parece se cruzar com o ímpeto criativo do artista do corpo, daquele que se abastece das angústias, do caos, da ira e da indignação para poder expressar, através da arte, escrituras ou manifestos para o mundo.

Com provas, sem provas, baseado em evidências ou em convicções (cabe aqui mencionarmos a teoria do domínio do fato ${ }^{27}$ ) o veredito já está estabelecido ad aeterno ${ }^{28}$.

\footnotetext{
${ }^{27}$ Disponível em: https://canalcienciascriminais.com.br/teoria-do-dominio-do-fato/. Acesso em: 14/02/18.

${ }^{28}$ Latim. Tradução: desde sempre.
} 
Figura 5- Cena de O Processo.

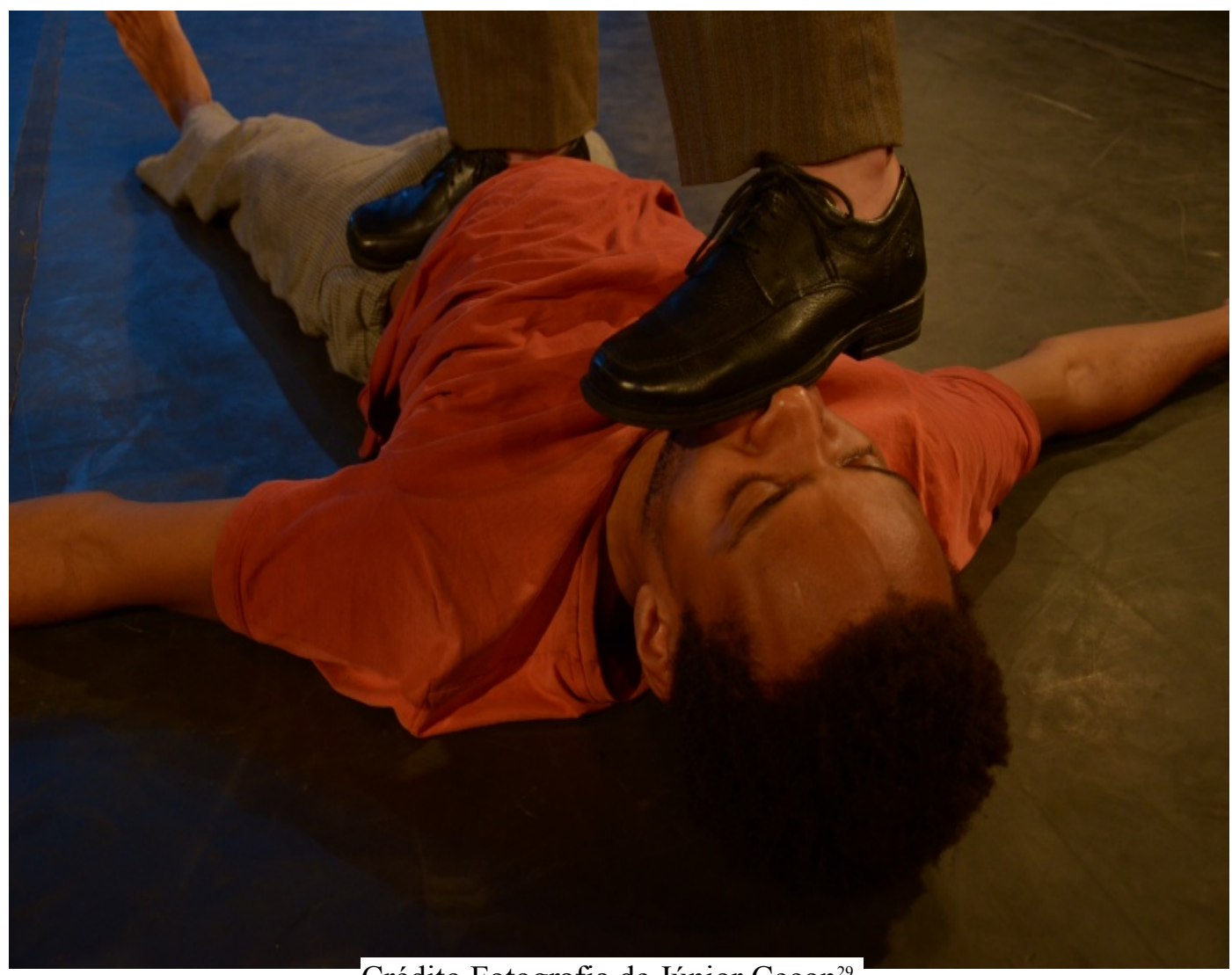

Crédito Fotografia de Júnior Cecon ${ }^{29}$.

Como em O Processo, de Franz Kafka, quando K, acusado sem conhecer a razão da acusação, e posteriormente condenado, recebe o veredito da pena de morte. Em suas últimas palavras proferidas em vida, com um punhal penetrado em seu peito, balbuciou: "Como um cão." (KAFKA, 2001, p. 278). Era como se a vergonha devesse sobreviver a ele.

Parece justo reconhecer em Tântalo a grandeza por sua incontrolável utopia (uma variação da insanidade?), talvez um herói inconteste, assim como os artistas na sua essência, onde o erro e o equívoco ressurgem como libertadores de verdades momentâneas e fúteis, onde as respostas deverão ser sempre provisórias.

Encerramos estas reflexões sobre Tântalo, ressaltando as tragédias que o corpo vem experimentando na história, com o momento final do Oficial, personagem criado por Kafka em $\mathrm{Na}$ Colônia Penal, morto em uma engrenagem de metal construída para torturar e executar condenados:

\footnotetext{
${ }^{29}$ Inspirada na obra homônima de Franz Kafka. Com Everton Ferreira e Amanda Santos. Disponível em: http://www.ciacarneagonizante.com.br. Acesso em: 15/05/18.
} 
Neste ato viu quase contra a vontade o rosto do cadáver. Estava como tinha sido em vida; não se descobria nele nenhum sinal da prometida redenção; o que todos os outros haviam encontrado na máquina, o oficial não encontrou; os lábios se comprimiam com força, os olhos abertos, tinham uma expressão de vida, o olhar era calmo e convicto, pela testa passava atravessada a ponta do estilete de ferro. (KAFKA, 1996, p.48)

Pensamos Tântalo como provedor do ato resiliente e doloroso, porém necessário, um contínuo murro em ponta de faca. ${ }^{30}$

\section{REFERÊNCIAS}

ALESSI, Gil. Brasil reescreve a sua história ao revelar detalhes da ditadura militar. El País - Brasil. 10 de dezembro de 2014. Disponível em:

https://brasil.elpais.com/brasil/2014/12/10/politica/1418212909 598291.html. Acesso em 24/02/18.

ANJOS, Augusto dos. EU - e outras poesias. Rio de Janeiro, Bertrand Brasil, 2001.

BOL. Chineses lotam estádio para ver traficantes serem condenados à morte. Notícias. 19 de dezembro de 2017. Disponível em: https://noticias.bol.uol.com.br/ultimas-noticias/internacional/2017/12/19/chineseslotam-estadio-do-pais-para-ver-traficantes-serem-condenados-a-morte.htm. Acesso em: 01/03/18.

BORELLI, Sandro. Sandro Borelli - Cia Carne Agonizante. Vídeo (Total: 6min13s; de 1min08s a 4min40s). Trecho do DOC Gestos Mortos. Captação e edição de imagens: Osmar Zampieri. Reedição para internet: Cia Carne Agonizante. Publicado em 2 de novembro de 2011. Disponível em:

https://youtu.be/mxyiGDK2GKk. Acesso em: 20/09/18.

BORELLI, Sandro. Centro de Referência da Dança da Cidade de São Paulo - A tradição e o cotidiano dançante no Vale do Anhangabaú. São Paulo: Cinelândia, 2015.

BRANDÃO, Junito de Souza. Mitologia Grega. I volume. Rio de Janeiro: Editora Vozes, 1986.

BRASILIANA FOTOGRÁFICA. Zumbi dos Palmares. 19 de novembro de 2015. Disponível em: http://brasilianafotografica.bn.br/?tag=zumbi-dos-palmares. Acesso em: 30/01/18.

COUTINHO et al. A Sentença de Tiradentes. Disponível em:

http://www.historianet.com.br/conteudo/default.aspx?codigo=612. Acesso em: 01/02/18.

DESCHAMPS, Luciane Mari. O mito dos centauros. Web Artigos. 07 de agosto de 2011. Disponível em: https://www.webartigos.com/artigos/o-mito-dos-centauros/73446. Acesso em: 03/01/18.

E-BIOGRAFIA. Joana D'arc. Disponível em: https://www.ebiografia.com/ioana darc/. Acesso em: $24 / 02 / 18$.

FUCKS, Rebeca. Romeu e Julieta, de William Shakespeare. Cultura Genial. Disponível em: https://www.culturagenial.com/romeu-e-julieta-de-william-shakespeare/. Acesso em: 13/03/19.

GABRIEL, Pedro. A Morte do Cisne, a Morte da Arte. 11 de dezembro de 2010. Disponível em: https://ituraterre.com/2010/12/11/a-morte-do-ciste-a-morte-da-arte/. Acesso em: 15/01/18.

${ }^{30}$ Disponível em: https://institutoaugustoboal.org/tag/murro-em-ponta-de-faca-2/. Acesso em 20/02/18. 
GLOBO NEWS. Saddam Hussein é enforcado no Iraque. Jornal das 10. Vídeo. Disponível em: http://g1.globo.com/globo-news/iornal-das-dez/videos/v/saddam-hussein-e-enforcado-no-iraque/1627912/. Acesso em: 01/03/18.

HISTORIANET. A sentença de Tiradentes. Disponível em: http://www.historianet.com.br/conteudo/default.aspx?codigo=612. Acesso em: 05/02/18.

KAFKA, Franz. Na Colônia Penal. Rio de Janeiro: Editora Paz e Terra, 1996.

KATZ, Helena. Diálogo possível e necessário entre dança e política. O Estado de São Paulo -Cultura. 13 de julho de 2013. Disponível em: http://cultura.estadao.com.br/noticias/geral,dialogo-possivel-e-necessarioentre-danca-e-politica-imp-, 1053054. Acesso em: 14/05/18.

MAPA DE LONDRES. Disponível em: https://mapadelondres.org/tag/execucoes-publicas. Acesso em: $03 / 01 / 18$.

MITOLOGIA Pt/BR. Daemones, os intermediários - Mitologia Grega. Disponível em: https://aminoapps.com/c/mitologicpt/page/blog/daemones-os-intermediarios-mitologiagrega/lDw7 wVFQuXk0QERdaqxERpXa1w4Jqaqrv. Acesso em: 13/03/19.

NIETZSCHE, Friedrich. O Nascimento da Tragédia. São Paulo: Editora Schwarcz, 2013.

O GLOBO. Poeta espanhol García Lorca foi preso e morto por militares, revelam documentos. Cultura. 23 de abril de 2015. Disponível em: https://oglobo.globo.com/cultura/livros/poeta-espanhol-garcia-lorca-foipreso-morto-por-militares-revelam-documentos-15959278. Acesso em: 01/03/18.

PORTAL SÃO FRANCISCO. Augusto dos Anjos. Disponível em:

https://www.portalsaofrancisco.com.br/biografias/augusto-dos-anjos. Acesso em: 01/01/18.

PRAGMATISMO POLÍTICO. Jovem negro é acorrentado nu em poste por grupo de 'justiceiros'. 03 de fevereiro de 2014. Disponível em: https://www.pragmatismopolitico.com.br/2014/02/jovem-negro-eacorrentado-nu-em-poste-por-grupo-de.html. Acesso em 13/03/19.

REVISTA USINA. Augusto dos Anjos - Poemas não recolhidos em livro pelo autor. Disponível em: https://revistausina.com/2016/12/30/augusto-dos-anjos-poemas-nao-recolhidos-em-livro-pelo-autor/. Acesso em: $24 / 02 / 18$.

ROBLE, Odilon José; ARAÚJO, Raíssa Guimarães de Souza. Introdução ao Grotesco nas Artes da Cena. Revista do Programa de Pós-Graduação em Artes da Escola de Belas Artes da UFMG. Belo Horizonte, v.6, 2016. Disponível em: https://eba.ufmg.br/revistapos/index.php/pos/index. Acesso em: 10/02/18.

SCHOPENHAUER, Arthur. A Metafísica do Belo. São Paulo: Editora UNESP, 2003.

SCHOPENHAUER, Arthur. A Vontade de Amar. Rio de Janeiro: Editora Ediouro, 1985.

SILVA, Douglas Rodrigues da. Entenda, de uma vez por todas, o que é a Teoria do Domínio do Fato. Canal Ciências Criminais. 09 de novembro de 2016. Disponível em:

https://canalcienciascriminais.com.br/teoria-do-dominio-do-fato/. Acesso em: 14/02/18. 


\section{NOTAS DE AUTOR}

AGRADECIMENTOS

À UNICAMP e a Tântalo.

CONTRIBUIÇÃO DE AUTORIA

Não se aplica.

FINANCIAMENTO

Não se aplica.

CONSENTIMENTO DE USO DE IMAGEM

Não se aplica.

APROVAÇÃO DE COMITÊ DE ÉTICA EM PESQUISA

Não se aplica.

CONFLITO DE INTERESSES

Não se aplica.

\section{LICENÇA DE USO}

Os autores cedem à Motrivivência - ISSN 2175-8042 os direitos exclusivos de primeira publicação, com o trabalho simultaneamente licenciado sob a Licença Creative Commons Attribution Non-Comercial ShareAlike (CC BY-NC SA) 4.0 International. Esta licença permite que terceiros remixem, adaptem e criem a partir do trabalho publicado, desde que para fins não comerciais, atribuindo o devido crédito de autoria e publicação inicial neste periódico desde que adotem a mesma licença, compartilhar igual. Os autores têm autorização para assumir contratos adicionais separadamente, para distribuição não exclusiva da versão do trabalho publicada neste periódico (ex.: publicar em repositório institucional, em site pessoal, publicar uma tradução, ou como capítulo de livro), com reconhecimento de autoria e publicação inicial neste periódico, desde que para fins não comerciais e compartilhar com a mesma licença.

\section{PUBLISHER}

Universidade Federal de Santa Catarina. Programa de Pós-Graduação em Educação Física. LaboMídia - Laboratório e Observatório da Mídia Esportiva. Publicado no Portal de Periódicos UFSC. As ideias expressadas neste artigo são de responsabilidade de seus autores, não representando, necessariamente, a opinião dos editores ou da universidade.

\section{EDITORES}

Mauricio Roberto da Silva, Giovani De Lorenzi Pires, Rogério Santos Pereira

\section{HISTÓRICO}

Recebido em: 14 de abril de 2019.

Aprovado em: 10 de junho de 2019. 